\title{
Afrografías. Representaciones gráficas y caricaturescas de los afrodescendientes
}

\author{
Historial de la reseña \\ Recibido: \\ 16 de diciembre de 2019. \\ Aceptado: \\ Rodrigo González Lagos ${ }^{\mathrm{a}}$ \\ a Facultad de Humanidades, Universidad de Santiago de Chile, Santiago, Chile. Correo electrónico: rodrigo.gonzalez.|@usach.cl
}

26 de diciembre de 2019.

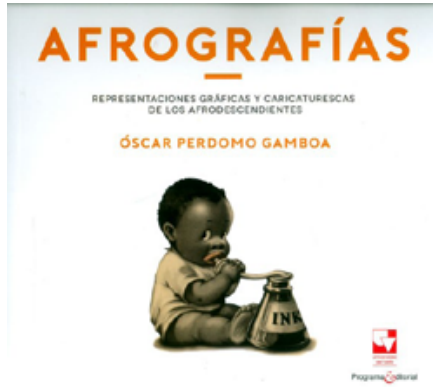

Afrografías. Representaciones gráficas y caricaturescas de los afrodescendientes

Óscar Perdomo Gamboa Programa editorial Universidad del Valle, Cali - Colombia, 2017, 268 pp
El libro Afrografías. Representaciones gráficas y caricaturescas de los afrodescendientes escrito por Óscar Perdomo Gamboa (comunicador social y periodista de la Universidad Autónoma de Occidente, Magíster en Literaturas colombiana y latinoamericana y Doctor en Humanidades por la Universidad del Valle), nace como interpelación al racismo gráfico y la manera cómo diferentes caricaturistas a través de los diarios, televisión y otros medios evidencian un racismo exacerbado que perpetúa la visión colonialista y racista sobre África y sobre las comunidades afro que se movilizaron o fueron desplazados hacia Latinoamérica.

Construido desde el campo de la comunicación social, el libro Afrografías compone una invitación a leer los discursos hegemónicos sobre población afrodescendiente a partir de un formato particular: ilustraciones, grabados, historietas y caricaturas de difusión masiva. El examen de más de trescientas láminas permitió reconstruir una clara línea argumentativa, la cual, oculta bajo la intrínseca abstracción visual y lingüística de los dibujos, muestra una continuidad de estereotipos y representaciones peyorativas, cuya presencia es transversal en ilustraciones históricas, publicitarias y lúdicas.

Al considerar la vasta compilación realizada, el libro invita a comprender la existencia de un naturalizado racismo gráfico que, además de extenderse por siglos, emerge desde locaciones altamente influenciadas por imaginarios coloniales. El libro llama la atención sobre las miradas travestidas desde el mundo occidental sobre el continente africano, sobre sus prácticas y formas de vida. Dicha percepción histórico eurocentrista es lo que ha permeado parte de las ignorancias e imaginarios al referir a un afro, sea afrocolombianos, afrodominicano, afrohaitiano, entre otros. Los imaginarios presentados en el libro, asimilan lo afro a salvajes, extraños, pobres, marginados o bizarros, por nombrar parte de los desconocimientos.

El libro es una reflexión para países como el nuestro, en tanto, la migración afro hacia Chile está colgada del imaginario eurocentrista sobre las comunidades negras. Según el autor, el imaginario sobre lo negro (a) es parte de la geografía actual la que ignora a su vez, la esclavitud y el aporte indígena. Desde la caricatura se evidencian las geografías racistas, pero también los lenguajes e ideologías que hacen del afro un ser no provisto de derechos. Dentro de los elementos más crudos de la grafía y el humor es la admisión de "trasgresiones, licencias y una suerte de irrupción instantánea" (p.50). 


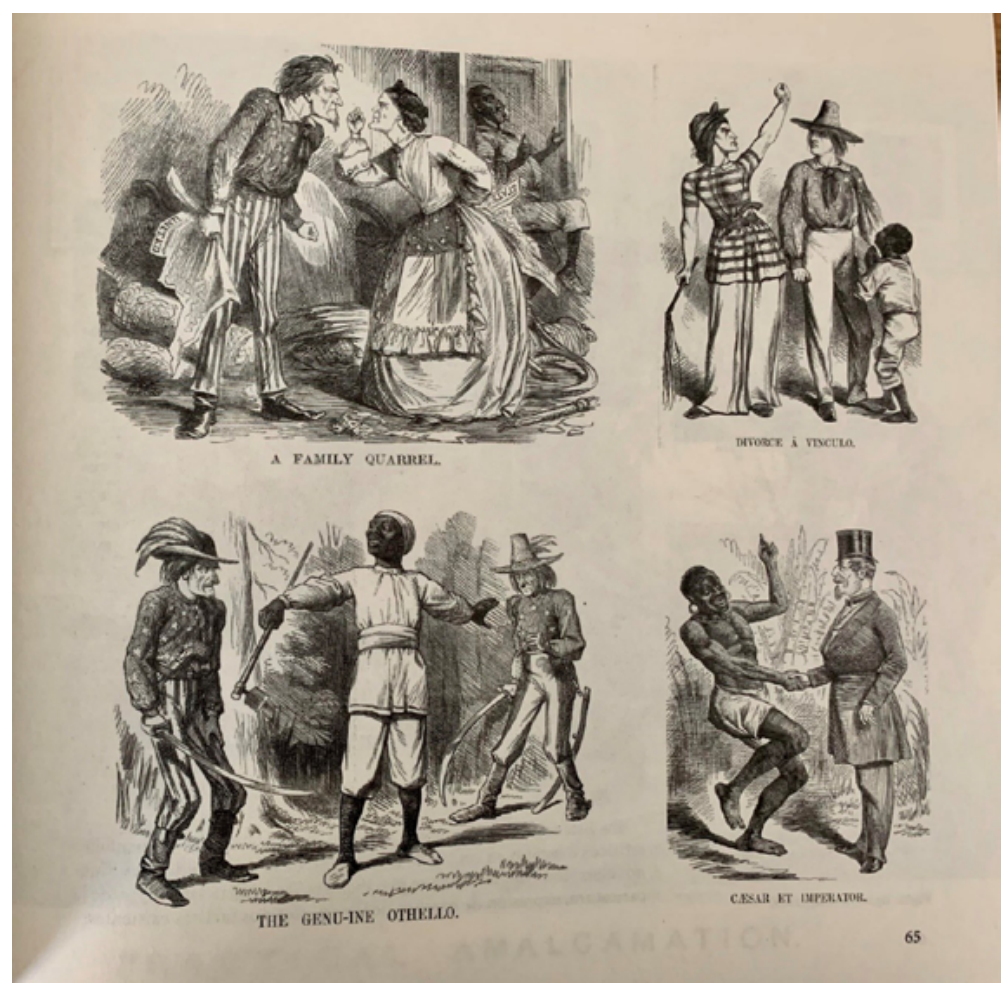

Figura 1. Caricaturas Siglo XVI. Fuente: Perdomo, O. (2017). Afrografías. Representaciones gráficas y caricaturescas de los afrodescendientes.
El origen académico de la caricatura se remonta a Italia de fines del siglo XVI, anclado en el seno de la familia Carraci (Fig. 1). Lo cuestionable, en el contexto actual, es que parte de las caricaturas racistas afloraban al momento que estudiantes salían a las calles a retratar personas con formas y grafías exageradas que serían parte de la consolidación en el siglo XIX de las caricaturas como modo de expresión, pero también, como práctica de burla y estereotipos. Esto último, exige cuestionarnos como académicos y académicas qué parte de nuestros ejercicios redundan en racismo académico y científico.

La geografía racista expresada a través de las caricaturas tuvo su auge desde 1860 , período de plena Guerra de secesión americana y de abolición de la esclavitud. Sin embargo, las publicaciones de arte secuencial gráfico referida a lo afro es anterior, siendo Europa y América referentes que pueden ser examinados en Afrografias. Lo más lamentable es que, indistintamente la década, los y las afro son grafiados en actitudes sumisas, suplicantes, pero también belicosas y activas, recreándose así un racismo que persiste hasta nuestra década ya sea a través de cantos, imágenes o incluso la forma de referirnos a los y las afro.

La evolución de la caricatura permea diferentes sociedades desde 1895, momento en que el autor refiere al nacer del "Yellow Kid y de las tiras cómicas" (p.69). Esta geografía de la caricatura racista, observable a través de las tiras que el autor recopila, devela el colonialismo imperante en nuestra región y en el mundo en general. Detrás de cada artista emerge un "artistas y editores blancos, europeos o norteamericanos, sobre los territorios colonizados y los afros recién emancipados" (p.71).

Posiblemente, como latinoamericanas y latinoamericanos llame la atención dentro del libro la caricatura de la "Palenquera"(Fig.2), personaje netamente colombiano que vende frutas en Cartagena y llevan en sus cabezas una olla con diferentes mercancías ¿Por qué podría llamar nuestra atención? Porque desde niños (as) éramos obligados a dibujar a las mujeres afro con diferentes cosas en la cabeza, sin cuestionarnos las condiciones de vida de ellas y el simbolismo tras los colores de vestidos asimilados a la bandera colombiana. A su vez, detrás de la palenquera se ocultaba maltrato y diferentes violencias a las que eran sometidas en sus lugares de nacimiento, pero también en los actuales espacios donde ellas habitan. Detrás de las palenqueras se teje también nuestra ignorancia en tanto desconocedora de los lugares donde ellas habitan y la forma cómo habitan. Esta geografía homogeneizante de lo afro oculta incluso, el rol de las sociedades blancas de estereotiparlos y marginalizarlos. 


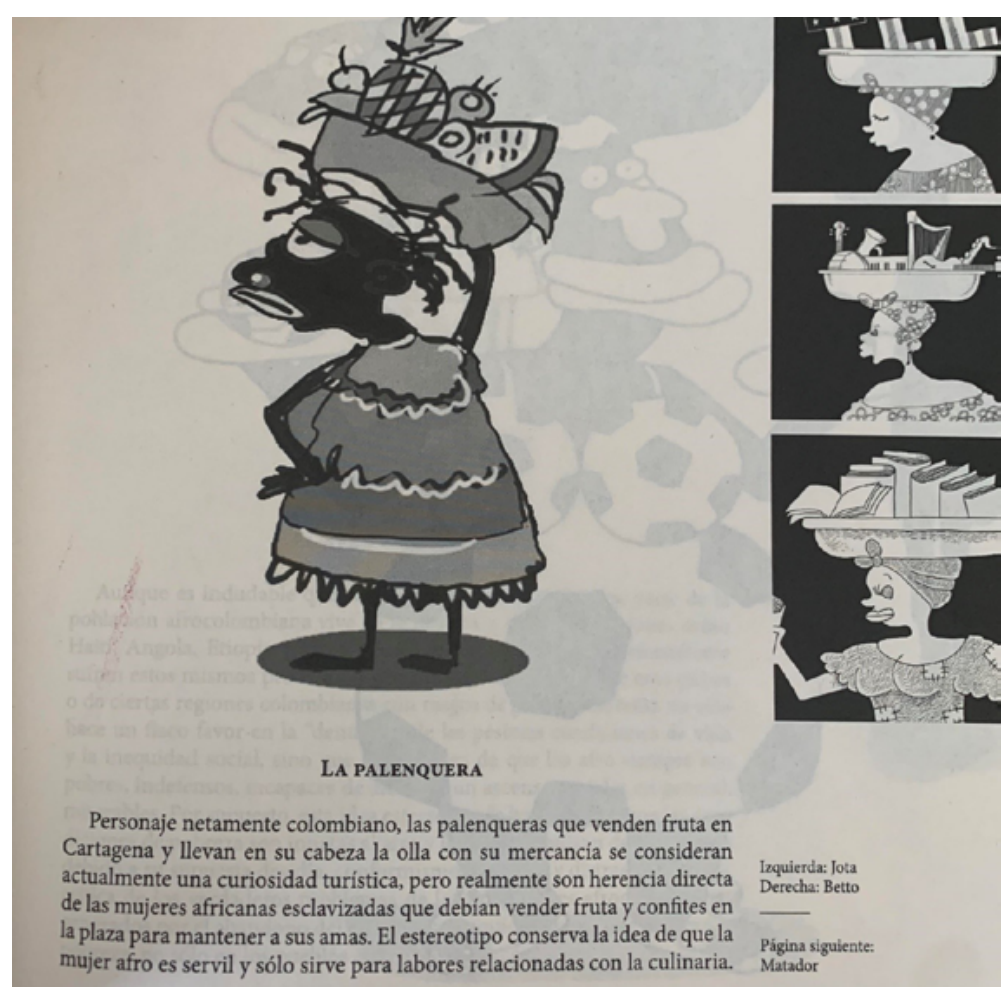

Figura 2. "La Palenquera". Fuente: Perdomo, O. (2017). Afrografías. Representaciones gráficas y caricaturescas de los afrodescendientes.
A lo largo del libro, el lector o la lectora se encontrará con una serie de ilustraciones que son desarrolladas por "artistas blancos para públicos blancos” (p.9). Aquello configuraría diversas geografías del racismo, cuyos discursos operarían bajo distintas escalas. En este sentido, el autor discute extensamente sobre las representaciones afrodescendientes en Colombia, quienes además de ser el grupo más afectado por la violencia política del pacífico son categorizados sistemáticamente por los medios según ciertas ocupaciones y corporalidades, lo que estigmatiza no solo a hombres y mujeres, en tanto la demarcación racista permea hacia sus territorios de residencia, tales como el Cauca o el Chocó.

Lo anterior, posiciona el libro como un referente y una lectura necesaria para aquellos (as) que trabajan sobre migración y racismo y desean construir discursos desde diferentes abordajes epistemológicos, empíricos y teóricos. La caricatura es otra de las formas de construir conocimiento y posicionar a un sujeto sobre otro.

El libro se organiza como un estado del arte teórico-descriptivo, iniciando desde la conceptualización de la caricatura para continuar con una revisión internacional e histórica de la representación afro, con especial énfasis en países de mayor producción gráfica como Estados Unidos. En ello se hace interesante observar el cambio de paradigma argumentativo, que en la década de los años incluyó discursos de multiculturalismo y diversidad racial, mientras en la actualidad reconoce la permanencia del racismo y conflictos entre y hacia las comunidades afrodescendientes. Este giro ocurre simultáneamente con la inclusión de otros formatos gráficos como historietas y el actual auge de novelas gráficas con protagonistas afrodescendientes. Desde aquello, el texto emprende la clasificación de los estereotipos y categorías del racismo predominantes en la gráfica colombiana, para finalizar destacando las caricaturas grotescas de personalidades afro como un ejemplo claro de la generalización y líneas editoriales racistas.

Analizar libros como Afrografias compone un interesante ejercicio para vincular la geografía a otras formas de conocimiento, pues permite redefinir qué tipo de insumos literarios son utilizados para la comprensión de fenómenos territoriales. Asimismo, el origen latinoamericano del texto llama a potenciar la revisión de literatura local, en tanto su lectura del racismo permitiría enriquecer el análisis de diversos procesos intrarregionales, entre ellos la migración. 